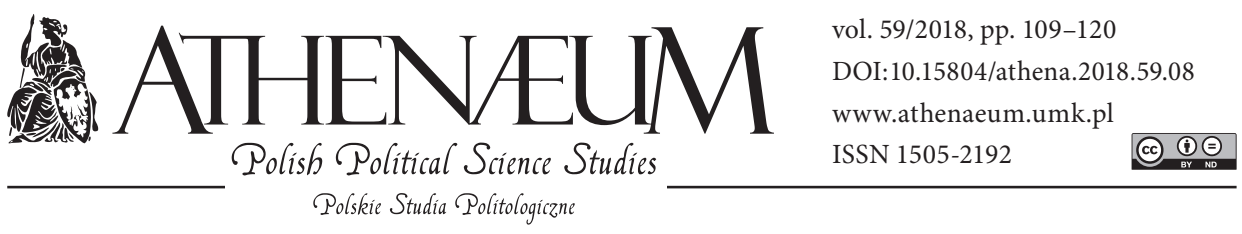

\title{
SPORTS EXCHANGE AS A TOOL OF SHAPING STATE'S IMAGE: THE CASE OF CHINA*
}

\author{
WYMIANA SPORTOWA JAKO NARZĘDZIE KSZTAŁTOWANIA \\ WIZERUNKU PAŃSTWA. PRZYPADEK CHIN
}

Michał Marcin Kobierecki**

\begin{abstract}
China is a country that employs a number of tools in order to shape its positive international perception. Sport plays an important role in this area. The aim of the research is to investigate the issue of sports exchanges and their role in shaping international image of China. The analysis is an empirical case study and is aimed at answering a research question concerning how sports exchanges may be used in order to shape a desired international image of a country. According to the main hypothesis to be tested in the article, through sports exchanges China managed to make a swift from the old, unidirectional sports diplomacy, to a more dialogue-oriented, reciprocal form.
\end{abstract}

Keywords: China, sports exchange, nationbranding, sports diplomacy, public diplomacy
Chiny należą do krajów, które wykorzystują szereg narzędzi kształtowania pozytywnego wizerunku międzynarodowego. Sport odgrywa w ich ramach istotną rolę. Celem badania jest analiza kwestii wymian sportowych i ich roli w kształtowaniu międzynarodowego wizerunku Chin. Badanie stanowi empiryczne studium przypadku i jego celem jest odpowiedź na pytanie badawcze dotyczące tego, w jaki sposób wymiany sportowe mogą być wykorzystane do kształtowania pożądanego wizerunku państwa. Zgodnie z główną hipotezą, która poddana została weryfikacji, przez wymiany sportowe Chiny były w stanie przejść od tradycyjnych form jednokierunkowej dyplomacji sportowej do bardziej ukierunkowanej na dialog i wzajemność.

Słowa kluczowe: Chiny, wymiany sportowe, branding narodowy, dyplomacja sportowa, dyplomacja publiczna

* The research has been financed by National Science Centre, Poland, within project number 2015/19/D/HS5/00513.

** University of Łódź, Faculty of International and Political Studies. 


\section{INTRODUCTION}

Nowadays, the issues of international image of a country, nation-branding and public diplomacy are gaining growing attention. Indexes of nations as brands are published annually, and policy-makers began to understand how important it is to manage the competitive identity of their countries. The states' activities in this field can have many forms, for example by using culture and sport. The aim of the research is to investigate the latter form.

China is an interesting example of a country that uses sport in order to shape its international image. Generally its branding objectives are typical as for such a big country and are oriented at changing the way it is perceived by the outside world to a more desirable one (Leonard \& Small, 2003) by countering negative stereotypes. According to Peter van Ham (2010), China wants to be seen as a country that cooperates, loves peace and develops, and that is ready to play a constructive role in international politics. In order to achieve those goals, China's government uses a number of central planned instruments of public diplomacy and nation-branding such as global media, as for example radio Voice of China, the Internet, organization of cultural and sports events, engaging Chinese emigrants as 'ambassadors' of the country. Those activities include the use of sport as well.

China's branding sports diplomacy focuses on organizing sports events, with the Beijing Olympics in 2008 as the key showcase of the country, and on attempting to gain international prestige through achieving high level in sport. Apart from that, PRC exploits sport for the sake of branding in different ways as well, through various types of sports exchanges, which shall be investigated in this article. This should allow to define good practices of such sports diplomacy, and to deepen the understanding of this research area.

The research presented in the article is an empirical case study concerning the use of sport exchanges as a tool of shaping a desirable image of a country externally. This issue was investigated on the example of China, a country that appears to be very advanced and experienced in such utilization of sport. An attempt to answer a research question concerning how sports exchanges may be used in order to shape a desired international image of a country was made. The research allowed to test a hypothesis stating that through sports exchanges China managed to make a swift from the old, unidirectional sports diplomacy, to a more dialogue-oriented, reciprocal form. In case of branding, such sports diplomacy allows to evoke mutual understanding and benefits for both parties. 
In contrast, the traditional sports diplomacy pursued by China often included intentional losing sports competitions and attempts to shape a desired image in a propaganda-style way.

\section{REVIEW OF LITERATURE}

The issue of the use of sport for the sake of shaping international image of states has been investigated for several years. Diplomatic Games: Sport, Statecraft, and International Relations Since 1945 edited by Heather L. Dichter and Andrew L. Johns appears to be the most comprehensive elaboration of this research area. A themed issue of Diplomacy \& Statecraft journal in 2016 and a number of monographs regarding the issue published lately give evidence to the growing interest of scholars. China belongs to the states that have been very deeply investigated in this field. Many publications referred to the famous Ping Pong diplomacy, for example works of Guoqi Xu (2008), Thomas F. Carter and John Sugden (2011), Yafeng Xia (2006). There have also been many publications about China's attempts to use sport for the sake of branding, including the already mentioned work of $\mathrm{Xu}$ (2008), and of such authors as Ingrid d'Hooghe (2015) or Anne-Marie Brady (2012). A number of articles in the themed issue of The International Journal of the History of Sport in 2010 are also worth mentioning. Despite the fact there is such a rich literature on the subject of the branding role of Chinese sports diplomacy, the existing analyses tend to focus on either hosting sports events, or on using sports victories in order to gain international prestige. The branding role of Chinese sports exchanges has hardly been investigated at all.

\section{SPORTS CONTACTS}

Sport has played an important role within Chinese public diplomacy. It is believed that it helped in reconstructing Chinese international image, both internally and externally (Hong \& Xiaozheng, 2005). Since the beginning of the $20^{\text {th }}$ century, sport was perceived by Chinese political leaders as a proper tool of diplomacy. In the Cold War era, it was used to put the country closer with the non-aligned and western states (Hong \& Zhouxiang, 2014), for example during the mentioned Ping Pong diplomacy, or when China wanted to achieve its leading position in 
the Third World through Games of New Emerging Forces. Of course China used sport to shape its relations with the communist states as well, at least before the split with the USSR. Athletes from the friendly countries that were visiting China were welcomed in a very hospitable way, often personally by high-profile politicians such as Prime Minister Zhou Enlai. During such exchanges, Chinese athletes were sometimes instructed to lose in the selected duels, in order to deepen the friendship between the countries (Hong \& Xiaozheng, 2005).

The Chinese attitude to sport changed after the end of Mao's era, when Deng Xiaoping took over the leadership in the country. The previous concept of 'friendship first, competition second' was changed into the obsession of winning in international sport $(\mathrm{Xu}, 2008)$. Such change of the attitude might have contributed to lesser priority of sports exchanges within Chinese branding sports diplomacy, as fierce sports competition is obviously not desirable within such friendly sports meets. Still, China did not resign from using sports exchange in order to shape its international image, but the emphasis was put on grassroots exchanges rather than in elite sport. Such people-to-people diplomacy is a typical form of public diplomacy.

Focusing on grassroots non-elite people's exchanges applied not only to sport, but to the general China's public diplomacy. Chinese authorities introduced a number of facilitations for foreign students that wanted to travel to China. For example, Chinese government and universities began to award scholarships to foreign students (Zhu, 2010). Foreign scholars became very welcome in China as well, similarly to the policy of the United States (Kurlantzick, 2007). If sport is considered, many grassroots exchanges have been initiated alongside the branding campaign conducted through hosting the Olympic Games in Beijing. At the time, more than 550 Chinese schools established sports and educational contacts with schools in other countries (Gratton, Preuss, \& Liu, 2015). Once the Games were over, China initiated a number of contacts with sports officials and sports federations in counties in Latin America, Central and South-East Asia - for example through a number of regional programmes for volunteers that include sports clinics. This referred to such states as Lao and Myanmar (Zhu, 2010; d'Hooghe, 2015).

China pursues similar type of branding sports diplomacy also in relation to the countries of the global North, for example, there is a vivid cooperation between China and the Czech Republic in ice hockey, having in mind the Olympic Winter Games that Beijing scheduled for 2022 (Fu, 2016). To celebrate the $35^{\text {th }}$ anniversary of normalization of relations with Japan, a year of cultural and sports 
exchange was announced (China Internet Information Center, 2007). Cooperation with the Unites States is very advanced, and since 2010 both countries hold U.S.China Consultation on People-to-People Exchange annually. The Sino-American sports exchanges include organization of seminars, exchange of athletes, hosting joint events (U.S. Department of State, 2016, 2011; Yu, 2014). Those exchanges are designed so that both sides should benefit from them, thus contributing to the enhancement of perception of China in the respective societies.

In analysing China's public diplomacy and nation-branding activity one must not forget about relations with Africa, a continent that for a long time has been the subject of interest of Chinese foreign policy. Holding sports exchange is actually one of the main activities that are conducted by the Forum on China-Africa Cooperation (Forum on China-Africa Cooperation, 2004). Their official goal is to strengthen the development of sport in the African countries, which is to be held on the basis of bilateral agreements on cultural cooperation (China Daily, 2015).

Sports exchanges that China establishes with other countries within its wider branding activities often take the form of sports development aid. This refers most of all to the developing states. In relations to such countries, China pursues a policy that has been called 'stadium diplomacy' (Alexander, 2014). For example, in 2007 China funded construction of a stadium in San Jose in Costa Rica (Zhu, 2010). This type of Chinese engagement very strongly referred to Africa, where for many years Chinese government has been funding public facilities, for example football stadiums, as a proof of friendship. For instance, the World Social Forum in Nairobi in 2007 was held at the stadium that was built by the Chinese (Melber, 2014). China's government took similar action in relation to the Pacific countries - in order to emphasise the image of a responsible global power in the region (Zhu, 2010).

Analysis of the character of sports exchanges between China and other countries led to an assumption that even though vast majority of them has been initiated be either central or local authorities in China, it is also held as a result of more grassroots activities. For example, one of Chinese telecommunication companies, Kejian (also named Keijian in the literature), has become a sponsor of the English Premier League football club Everton. The sponsorship agreement is basically aimed at strengthening the company's brand by putting its logo and name on the team's uniforms (Roll, 2006), but also at the exchange of players and coaches, a team's tour in China at the end of the season, and training of Chinese young players by Everton (Jones, 2004). This way as a result of a private initiative by a Chinese company various sports exchanges have been established. 
The review of the types of sports exchanges conducted by China within its branding activities reveals that there is a clear difference in China's tactics in relation to the developed and developing countries. The sports contacts with the wealthier states encompass most of all people-to-people exchanges and knowledge sharing, with bilateral benefits. Such activities are typical for the new type of public diplomacy and are conducted by countries with rich traditions in this field, such as the United States. On the other hand, the exchanges with the developing countries usually have a more asymmetrical form and often focus on providing development aid, for example by financing construction of sports facilities, sending volunteers and coaches. Such diversification appears to be very reasonable and justified, tailored to the needs and expectations of particular partners.

\section{SPORTS PERSONALITIES AS PUBLIC DIPLOMACY 'AMBASSADORS'}

Analyses of the use of sport in nation-branding of China often refer to the issue of engaging well-known athletes as a kind of 'ambassadors' of the country. This is derived from the assumption that foreign athletes performing in the world's best sports leagues may bring global gains to country's public diplomacy. It is because when they - for example - give an interview or receive a prize for the player of the match, their nationality is presented as well (Pigman, 2014). Chinese decision-makers appear to share such view.

In compliance with such stand, China's government tries to use the global recognisability of its best athletes. Sports stars like basketball player Yao Ming or Manchester United's football player Sun Jihai have been willingly sent to play abroad by the governments since late 1990s. They therefore work as 'cultural ambassadors' in order to bring China closer to the outside world (Zhu, 2010). The other Chinese sports stars that played similar role were, for example, a world record holding hurdler Liu Xiang - a man that alongside with Yao Ming was described by Stuart Murray and Geoffrey Pigman as a "part-time Chinese envoy" (2014, p. 1103). Female tennis players Yan Zi and Zheng Jie, which won Wimbledon doubles in 2006, gymnasts Li Xiaopeng and Liu Xuan, diver Guo Jingjing, table tennis players Zheng Jie and Peng Shuai, figure skating 2009 world champions Shen Xue and Zhao Hongbo were also regarded as meaningful in shaping the positive brand of China (Lai, 2012). There are ambiguous opinions about the branding contribution of a winner of tennis grand slams $\mathrm{Li} \mathrm{Na}$, who 
often distanced herself from her homeland, but at the same time, revealed a great potential in strengthening the international image of China and was supported by Chinese authorities (McDonnell, 2014; Branigan, 2011).

A basketball player Yao Ming was probably an athlete that fostered international image of China in the strongest way possible. He was a number-one pick by Houston Rockets in 2002 draft and at the same time the first Chinese without previous basketball experience in the United States to play in NBA. He was developing very quickly as a player, but due to health problems only played for nine seasons. In this time, he was voted onto the All-Stars to star for the Western Conference in the All-Star Game eight times, and was named in the All-NBA Team five times (Quingmin, 2013). Once he ended his athletic career, he engaged himself in coaching young players and in social activities.

Yao Ming is believed to have contributed to the fact that there are millions of NBA fans in China, and at the same time, to have presented the 'new China' to millions of Americans. When he was playing for Houston Rockets, reporters from China followed his every move, American fans were wearing Chinese national team jerseys and many arenas welcomed him with dragon dancers. As former US Ambassador to China James Sasser noted, "Yao Ming gave the Chinese people and China a human face in the United States" (Murray, 2016, p. 619). His role in overcoming negative stereotypes appears to have been the most important. Yao was able to do this because of his sports talent and personality traits. According to Sheng Ding (2008), Yao Ming was "the exact personification of China's growing soft power - affable, strong, confident without being arrogant, and focusing on success" (p. 70). These are the attributes that Beijing would like to be associated with. It was also very important that contrary to many other sports stars, Yao Ming was never an object of any scandal. He was also able to charm people with his sense of humour, thus countering a stereotype that Chinese do lack this feature. At the same time, Yao promoted Chinese culture, for example by organizing cultural shows in the breaks of the matches (Quingmin, 2013).

It is believed that Yao Ming showed the world new, softer image of China. Thanks to him, "a new demographic of Asian fans has flocked to stadiums to watch the giant stride across court, offering an image of China that has nothing to do with Chairman Mao or massacres at Tiananmen Square" (Rawnsley, 2009, p. 285). His activity helped to shape more positive perception of China in the United States and worldwide, but at the same time, he contributed to better attitude of Chinese society towards the USA - as a country that welcomed their national hero warmly, not a superpower with contrary interests (Quingmin, 
2013). Such two-way direction of the sports exchange effects is typical for the new public diplomacy.

Bearing in mind Yao Ming's contribution to shaping international image of China, it should be no surprise that Chinese government supported him heavily "as a global spokesperson and representative for Chinese culture, modernity, and progress" (Murray, 2013, p. 13). The basketball player was also one of the key figures of the Olympic Games in Beijing, for example, he was the flagbearer for the Chinese national team during the opening ceremony. Taking him as a rolemodel, Chinese government perceives sending its best players to foreign leagues including NBA as an investment in its brand (Ding, 2008). It is at the same time another way of political utilizing elite sport system in China, alongside achieving general high level in sport, which is also believed to be a soft power resource.

\section{CHINESE SPORTS LEAGUES}

Currently we can observe another way China attempts to use sports exchanges in order to shape its international image. This refers to global engagement of Chinese sports leagues, particularly the football league. Since the beginning of the $21^{\text {st }}$ century, Chinese teams have been actively trying to establish international connections. In 2001-2002 season, 50 foreign coaches and players were hired, most of whom were coming from Russia, Yugoslavia, Croatia, Brazil, Paraguay, Uruguay, South Korea, Iran, and Saudi Arabia. On the other hand, local football unions in China were establishing cooperation with English football clubs concerning youth training (Jones, 2004). The diplomatic significance of such grassroots initiatives was not relevant, but generally each contact on the people-to-people level should be regarded as a potential tool for shaping the international perception of a country.

If the branding role of Chinese sports leagues is considered, a recent trend of hiring global football stars by Chinese leagues that were able to spend enormous sums on their salaries blew minds of the sports experts in the world. J. Simon Rofe (2016) cited Arsenal F.C. manager Arsène Wenger noting that "China looks to have the financial power to move the whole league of Europe to China" ( $p$. 212), in the context of outbidding Premier League's Liverpool F.C. offer to acquire Brazilian midfielder Alex Teixeira from the Ukrainian Shakhtar Donetsk by Chinese Jiangsu Suning. At the same time, the French coach recognized 'political desire' for such operations from China's government. The total expenditure of the 
Chinese football teams during the 2016 winter transfer window was estimated for $258 \mathrm{mln}$ Euro, whereas rich teams of the English Premier League spent $227 \mathrm{mln}$ Euro. At the time, few world-known players signed their contracts with Chinese teams, among them Jackson Martinez from Athletico Madrit - with Guangzhou Evergrande, Gervinho from Arsenal F.C. - with Hebei Fortune FC, and Paulinho from Totenham - with Guangzhou Evergrande (Kilpatrick, 2016). The issue was back in agenda during the 2017 winter transfer window, when for example Oscar was acquired from Chelsea London for between 60 and $70 \mathrm{mln}$ Euro by Shanghai SIPG, while Carlos Tevez was granted $40 \mathrm{mln}$ Euro annual salary by Shanghai Greenland Shenhua (Kręcidło, 2017).

Chinese football clubs that were spending great sums on transfers from foreign leagues have been receiving an indirect support from Chinese government - the companies who own the 16 clubs in the Chinese Super League perceive their investment as a way of gaining favour with the government (Price, 2017), as it is believed that Chinese leader since $2013 \mathrm{Xi}$ Jinping is a football enthusiast (Rofe, 2016). However, early in 2017, Chinese government criticized 'irrational' expenditure of Chinese football clubs and claimed it would "regulate and restrain high-priced signings, and make reasonable restrictions on players' high incomes" (AS, 2017). Such decision may possibly reverse a trend, but there can still be inquiries whether such global engagement of Chinese football should be seen from the perspective of shaping international image of the country. Strong sports league is obviously a soft power resource, as it contributes to greater publicity and general enhancement of the country's perception. Strong sports clubs may act in a similar way as sports ambassadors that were mentioned earlier. For now it remains unclear whether such is the aim of the China's government.

\section{CONCLUSION}

China is a sophisticated and advanced state concerning the utilization of sports exchanges in order to shape its international image. Its activities encompass various types of sports contacts, including sports development aid, as well as softer ways of enhancing its positive publicity in the media overseas - through engaging China-born global sports stars and, lately, the economic potential of its football league. Those undertakings appear to be thought-through and tailored to their targets, for example, there is a clear distinction between Chinese activity in relations to developed countries and to the developing nations. 
The hypothesis stating that through sports exchanges China managed to change the face of its sports diplomacy into a more soft and reciprocal one is highly probable. Bearing in mind the ways China used sport for the sake of shaping its international perception in the past, contemporary sports exchanges are a completely new quality. Apart from sports development aid, Chinese government appears to use other actors in order to shape its image rather than engaging directly. It supports sports stars such as Yao Ming, and attracts people from other countries through sports exchanges between schools, sports clubs, voluntary organizations, etc. Such utilization of sport for the sake of branding have been called in the literature 'sports diplomacy 2.0' - it is facilitated by networks of traditional diplomats working alongside CSOs, IGOs, sports people and corporations that engage, inform and create a favourable image of the state (Murray, 2016). Of course China did not resign from exercising more propaganda-style sports diplomacy, which could have been seen during the Olympics in Beijing in 2008, but apparently it is becoming more subtle these days.

\section{ReFERENCES:}

Alexander, C.R. (2014). China and Taiwan in Central America: Engaging Foreign Publics in Diplomacy. New York: Palgrave Macmillan.

AS (2017). Chinese Government to Impose Spending Limit on Transfers and Wages. Retrieved from: http://en.as.com/en/2017/01/05/football/1483618683_270444. html.

Brady, A.M. (ed.) (2012). China's Thought Management. Abingdon: Routledge.

Branigan, T. (2011). Li Na, a Singular Lady Leading China’s Long March to Glory. The Guardian. Retrieved from: https://www.theguardian.com/sport/2011/jun/19/ li-na-china-wimbledon-2011.

Carter, T.F., \& Sugden, J. (2011). The USA and Sporting Diplomacy: Comparing and Contrasting the Cases of Table Tennis with China and Baseball with Cuba in the 1970s. International Relations, 26(1), 101-121. DOI: 10.1177/0047117811411741.

China Daily (2015). China's Second Africa Policy Paper. Retrieved from: http://www. chinadaily.com.cn/world/XiattendsParisclimateconference/2015-12/05/content_22632874.htm.

China Internet Information Center (2007). China-Japan Year of Cultural \& Sports Exchanges. Retrieved from: http://www.china.org.cn/english/features/Exchanges /203890.htm.

d'Hooghe, I. (2015). China's Public Diplomacy. Leiden: Brill.

Dichter, H.L., \& Johns, A.L. (eds.) (2014). Diplomatic Games: Sport, statecraft, and International Relations Since 1945. Lexington: University Press of Kentucky. 
Ding, S. (2008). The Dragon's Hidden Wings: How China Rises with Its Soft Power. Plymouth: Lexington Books.

Forum on China-Africa Cooperation (2004). Programme for China-Africa Cooperation in Economic and Social Development. Retrieved from: http://www.focac.org/eng/ wjjh/hywj/t157834.htm.

Fu, J. (2016). Sports Chiefs: Together We Can Achieve Our Olympic Goals. China Daily. Retrieved from: http://europe.chinadaily.com.cn/epaper/2016-03/25/content_24087579.htm.

Gratton, C., Preuss, H., \& Liu, D. (2015). Economic Legacy to Cities from Hosting Mega Sports Events: A Case Study of Beijing 2008. In: R. Holt, \& D. Ruta (eds.), Routledge Handbook of Sport and Legacy: Meeting the Challenge of Major Sports Events (pp. 46-58) Abingdon: Routledge.

Hong, F., \& Xiaozheng, X. (2005). Communist China: Sport, Politics and Diplomacy. In: J.A. Mangan, \& F. Hong (eds.), Sport in Asian Society: Past and Present (pp. 258-276). London: Routledge.

Hong, F., \& Zhouxiang, L. (2014). Politics First, Competition Second: Sport and China's Foreign Diplomacy in the $1960^{\text {s }}$ and 1970s. In: H.L. Dichter, \& A.L. Johns (eds.), Diplomatic Games: Sport, Statecraft, and International Relations Since 1945 (pp. 385-408). Lexington: University Press of Kentucky.

Jones, R. (2004). Football in the People's Republic of China. In: W. Manzenreiter, \& J. Horne (eds.), Football Goes East: Business, Culture and the People's Game in China, Japan and South Korea (pp. 54-66). New York: Routledge.

Kilpatrick, J. (2016). Jackson Martinez, Ramires and Tim Cahill... stars who play in China. Sky Sports. Retrieved from: http://www.skysports.com/football/ news/11096/10145890/five-former-premier-league-stars-who-play-in-china.

Kręcidło, J. (2017). Koniec finansowego Eldorado? Chińczycy chcą ograniczyć pieniądze na transfery! Przeglad Sportowy. Retrieved from: http://www.przegladsportowy. pl/pilka-nozna/transfery,chinski-rzad-chce-ograniczyc-pieniadze-na-transfery-wchinese-super-league,artykul,748171,1,970.html.

Kurlantzick, J. (2007). Charm Offensive: How China's Soft Power Is Transforming the World. New Haven: Yale University Press.

Lai, H. (2012). China's Cultural Diplomacy: Going for Soft Power. In: H. Lai, \& Y. $\mathrm{Lu}$ (eds.), China's Soft Power and International Relations (pp. 83-103). London: Routledge.

Leonard, M., \& Small, A. (2003). Norway's Public Diplomacy: Executive Summary. Retrieved from: https://www.regjeringen.no/globalassets/upload/ud/vedlegg/ public.pdf.

McDonnell, J. (2014). Li Na: Breathing Life into Tennis and China's Image. The Diplomat. Retrieved from: http://thediplomat.com/2014/03/li-na-breathing-life-into-tennisand-chinas-image/.

Melber, H. (2014). Africa and China: Old Stories or New Opportunities. In: T. Murithi (ed.), Handbook of Africa's International Relations (pp. 333-342). Abingdon: Routledge. 
Murray, S. (2013). Moving Beyond the Ping-Pong Table: Sports Diplomacy in the Modern Diplomatic Environment. Public Diplomacy Magazine, 9, 11-16.

Murray, S. (2016). Sports Diplomacy. In: C.M. Constantinou, P. Kerr, \& P. Sharp (eds.), The SAGE Handbook of Diplomacy (pp. 617-627). London: SAGE.

Murray, S., \& Pigman, G.A. (2014). Mapping the Relationship Between International Sport and Diplomacy. Sport in Society: Cultures, Commerce, Media, Politics, 17(9), 1098-1118. DOI: 10.1080/17430437.2013.856616.

Pigman, G.A. (2014). International Sport and Diplomacy's Public Dimension: Governments, Sporting Federations and the Global Audience. Diplomacy \& Statecraft, 25(1), 94-114. DOI: 10.1080/09592296.2014.873613.

Price, S. (2017). Why Chinese Clubs Are Breaking Transfer Records - And Why Players Are Wise to Go. The Guardian. Retrieved from: https://www.theguardian. com/football/these-football-times/2017/jan/05/china-chinese-super-league-oscarcarlos-tevez.

Quingmin, Z. (2013). Sports Diplomacy: The Chinese Experience and Perspective. The Hague Journal of Diplomacy, 8(3-4) , 211-233. DOI: 10.1163/1871191X-12341257.

Rawnsley, G.D. (2009). China Talks Back: Public Diplomacy and Soft Power for the Chinese Century. In: N. Snow, \& P.M. Taylor (eds.), The Routledge Handbook of Public Diplomacy (pp. 282-291). New York: Routledge.

Rofe, J.S. (2016). Sport and Diplomacy: A Global Diplomacy Framework. Diplomacy \& Statecraft, 27(2), 212-230. DOI: 10.1080/09592296.2016.1169785.

Roll, M. (2006). Asian Brand Strategy: How Asia Builds Strong Brands. Basingstoke: Palgrave Macmillan.

The International Journal of the History of Sport, 27(9-10), June-July 2010. DOI: $10.1080 / 09523367.2010 .481136$.

U.S. Department of State (2011). U.S.-China CPE Cooperation on Sports: Fact Sheet. Retrieved from: https://2009-2017.state.gov/r/pa/prs/ps/2011/04/160628.htm.

U.S. Department of State (2016). U.S.-China Consultation on People-to-People Exchange: Fact Sheet. Retrieved from: https://2009-2017.state.gov/r/pa/prs/ps/2016/06/258141. htm.

van Ham, P. (2010). Social Power in International Politics. London: Routledge.

Xia, Y. (2006). Negotiating with the Enemy: U.S.-China Talks during the Cold War, 1949-1972. Bloomington: Indiana University Press.

Xu, G. (2008). Olympic Dreams: China and Sports 1895-2008. Cambridge: Harvard University Press.

Yu, H. (2014). China's Diplomacy in Non-traditional Areas. In: J. Yang (ed.), China's Diplomacy: Theory and Practice (pp.327-414). Hackensack: World Century Publishing Company.

Zhu, Z. (2010). China's New Diplomacy: Rationale, Strategies and Significance. Farnham: Routledge. 